\title{
INSPECTING THE ROLE OF EMPOWERMENT, OSTRACISM, DEFENSIVE SILENCE AND EMPLOYEE PROACTIVITY WITH RELATION TO EMPLOYEE CREATIVITY AND ORGANIZATIONAL PERFORMANCE
}

\author{
Dr. Ali Dalain \\ Associated Professor, College of Business, University of Jeddah, Jeddah, Saudi Arabia \\ Email: ali-dalain@yahoo.com
}

\begin{abstract}
Purpose: This study attempts to gain insight into what factor influence on employee creativity and perceived organizational performance. Therefore, a theoretical framework is developed grounded in empowerment theory workplace ostracism and defensive silence. In addition to that the moderating role of employee proactivity is hypothesized between employee creativity and perceived organizational performance.

Design/Methodology/Approach: The research design of this study is based on positivist paradigm and followed quantitative research approach. A survey was administered towards public sector organizations in Saudi Arabia. Sample size of this study is computed with priorpower analysis using G-power software. For data analysis 384 responses were analyzed with structural equation modeling (SEM).
\end{abstract}

Findings: Results indicate that employee creativity is predicted by empowering leadership, psychological empowerment, structural empowerment, trust in leadership, defensive silence and workplace ostracism and explained $R^{\wedge} 252.4 \%$ variance in employee creativity. Therefore, employee creativity and employee proactivity shows $R^{\wedge} 255.1 \%$ variance in perceived organizational performance. Effect size analysis $\left.[(f)]^{\wedge} 2\right)$ showed that structural empowerment had medium level of effect size when predicting employee creativity.

Practical Implications: This study contributes to empowerment theory and enriches the innovative and leadership literature. Practically, this research suggested that managers and policy makers should focus on empowering leadership, structural empowerment, psychological empowerment, employee proactivity and trust in leadership in order to boost employee creativity and perceived organizational performance.

Originality/value: This research is significant as it extends the empowerment theory with defensive silence and workplace ostracism and extends the body of knowledge on this subject. To the best of researcher knowledge this study is the first that test the empowerment theory with the moderating role of employee proactivity to determine employee creativity and perceived organizational performance.

Keywords: Workplace ostracism; Defensive Silence; Empowering Leadership; Psychological Empowerment ; Employee Proactivity; Structural equation modeling.

Acknowledgement: This work was funded by the University of Jeddah, Saudi Arabia, under grant No. (UJ-20-061-DR). the authors, therefore, acknowledge with thank the university technical and financial support.

\section{Introduction}

Today's volatile and dynamic environment requires employee to work under their own initiative without relying on supervisor instructions (Binyamin \& Brender-Ilan, 2018). In this essence, empowerment plays a central role to foster and nurture employee proactivity and creativity which in turn enhance organizational performance (Parker, Wang, \& Liao, 2019). Affirmative and interactive relationship between leaders and subordinates enhance empowerment and helps employees to achieve organizational and strategic goals timely (Ha \& Lo, 2018; Park, Kim, Yoon, \& Joo, 2017). Extending to this, literature has showed that Inter-social relationship among employee increase employee job satisfaction, employee creativity and perceived organizational performance (Farmer, Van Dyne, \& Kamdar, 2015; Hirst, Van Dick, \& Van Knippenberg, 2009; Wang \& Noe, 2010). There is solid evidence that empowering leadership, psychological empowerment, structural empowerment and trust in leadership significantly influence on employee creativity (Dirks \& Ferrin, 2002; Fernandez \& Moldogaziev, 2013; Jain, Duggal, \& Ansari, 2019; Schaubroeck, Lam, \& Peng, 2011; Singh \& Rangnekar, 2020; Spreitzer, 2008; Wong \& Kuvaas, 2018). According to Parker et al. (2019), employees with empowerment characteristics are found more satisfied and 
creative at workplace. Therefore, investigating the role of empowerment factors is important to understand what factors impact on employee creativity and perceived organizational performance.

The role of empowering leadership has studied previously in the context of team performance, team effectiveness, increased organizational flexibility, service performance and organizational performance (Parker et al., 2019; Tierney, Farmer, \& Graen, 1999; Zhou \& George, 2003). Therefore, little is discussed about empowering leadership and employee creativity (Singh \& Rangnekar, 2020). The current study fills this research gap and proposed a new research model underlying factors namely empowering leadership, psychological empowerment, and structural empowerment in the context of employee creativity. Another aspect of this research is to investigate factors that negatively impact on employee creativity. According to Chung (2018) workplace ostracism and defensive silence negatively influence on employee creativity and organizational performance. Thus, the role of workplace ostracism and defensive silence is studied with relation to employee creativity. Workplace ostracism is a feeling of an employee that he/she is intentionally excluded in a group and is being ignored. Therefore, defensive silence is a situation wherein individual suppress facts, views and ideas with a fear of negative consequences such as job termination or denial in promotion (Chenji \& Sode, 2019). Hence, examining the role of work place ostracism and defensive silences is vital for human resource managers. Finally, this study examines the moderating role of employee proactivity following argument asserted by Singh and Rangnekar (2020) stated that employees proactive work behaviour influence on employee creativity and enhance organizational performance. The moderating role of employee proactivity is hypothesised in such a way that it strengthens the relationship between employee creativity and perceived organizational performance. This study has three main objectives: First, it investigates the positive impact of empowering leadership, psychological empowerment and structural empowerment on employee creativity. Second, workplace ostracism and defensive silence are added into the research model to understand how these factors negatively impact on employee creativity. Third, the moderating role of employee proactivity is tested between employee creativity and perceived organizational performance. The current research is significant as it develops an amalgamated model that includes positive and negative factors to investigate employee creativity and perceived organisational performance.

\section{Literature review}

\subsection{Empowering leadership}

The term empowering leadership is defined as leadership style that provides autonomy to employee to actively participate in decision making, enhance employee outcome and remove bureaucratic constraints (Wong \& Kuvaas, 2018). Empowering leadership practices enhance meaningful work of employee and bring creativity at work place (Chow, 2018). According to Singh and Rangnekar (2020) individual who feels empowered at workplace are found more satisfied with their job, life and career. In addition to that employees working under empowered leadership had showed commitment with their job which in turn increases performance of the organization. Earlier studies had confirmed strong relationship between empowering leadership and employee creativity Harris, Li, Boswell, Zhang, and Xie (2014); Srivastava, Bartol, and Locke (2006); Zhang and Bartol (2010). Thus, the relationship between empowering leadership and employee creativity is theorized as:

\section{H1: Empowering leadership is positively relates to employee creativity.}

\subsection{Structural empowerment}

The structural empowerment is a macro approach of empowerment and defined as a set of practices and policies that enables transfer of power and authority in organizations from higher level to lower level (Dewettinck \& van Ameijde, 2011). Structural empowerment is actually a managerial initiated socio structural phenomenon (Biron \& Bamberger, 2010). The empowerment theory introduced by Bowen and Lawler III (2006) and revealed four aspects of structural empowerment including; power to make decision, information, knowledge and reward. It is argued that organizations can transfer power following these four structural elements (Fernandez \& Moldogaziev, 2013). The structural empowerment is investiagted in human relation movement, employee involvement, employee participation, jod analysis and design related studies (Maynard, Luciano, D'Innocenzo, Mathieu, \& Dean, 2014; Spreitzer, Kizilos, \& Nason, 1997). Empirical evidence showed that structural empowerment positively relates to employee creativity, employee productivity and financial performance of the organizations (Birdi et al., 2008; Ganster, 2008; Jiang, Lepak, $\mathrm{Hu}$, \& Baer, 2012; Maynard, Gilson, \& Mathieu, 2012; Patterson, West, \& Wall, 2004; Wallace, Johnson, Mathe, \& Paul, 2011). Therefore, structural empowerment is hypothesised as:

\section{H2: Structural empowerment is positively relates to employee} creativity.

\subsection{Psychological empowerment}

The psychological empowerment is a micro approach to empowerment and referred to employee psychological state, their attitude and reaction towards managerial practices (Dewettinck \& van Ameijde, 2011). According to Conger and Kanungo (1988), psychological empowerment reflects to 
employee belief that they show towards their work. Extending to this Spreitzer (2008) stated that psychological empowerment is a motivational constructs which comprises four different dimensions namely; competence, impact, meaning, and self-determination. Competency is referred to employee believes that they are able to perform a task or activity. The second dimension is meaning and seen as the extent in which employee judge that job is ideal according to his/her standard. Therefore, impact refers to employee believe that they have influence over outcome at workplace. The selfdetermination character of empowerment explained that employee has choice in initiating a task or activity (Spreitzer, 2008). Literature on employee psychological empowerment has confirmed that employees with positive psychological empowerment influence on employee creativity and augment organizational performance (Auh, Menguc, \& Jung, 2014; Cuenca Cervera, 2011; Deci \& Ryan, 2000; Houston, 2000; Mostafa, Gould-Williams, \& Bottomley, 2015; ShapiraLishchinsky \& Tsemach, 2014; Taylor, 2013). Thus, psychological empowerment is proposed as:

H3: Psychological empowerment is positively relates to employee creativity.

\subsection{Trust in leadership}

Trust in leadership creates strong relationship between supervisor and subordinate (Laschinger, Wong, \& Grau, 2012). Trust in leadership has been identified as "the willingness of a trustor vulnerable towards actions of a trustee that the trustee will fulfil a particular action based on anticipation" (Jain et al., 2019). It is a psychological state where an individual willingness to be vulnerable is linked to other individual action without monitoring individual behaviour (Alkaabi \& Wong, 2019). According to Jain et al. (2019) the relationship between trustworthy leader and subordinates can be achieved through integrity, honesty and moral leadership standard. These attributes brings positive expectation among employees and enhance their willingness to accomplish organizational goal (Alkaabi \& Wong, 2019). Another study conducted by Laschinger et al. (2012) revealed that an authentic leader increase trust in subordinate which in turn enhance confidence in followers and help them to achieve firm goals. The literature has revealed a positive relationship between trust in leadership and employee creativity (Dirks \& Ferrin, 2002; Jain et al., 2019; Schaubroeck et al., 2011). The relationship that is developed by trust in leadership generates confidence in employees and help them to produce creative work (Edmondson, 1999; Gong, Cheung, Wang, \& Huang, 2012). Earlier studies have confirmed positive relationship between trust and employee creativity Bartram and Casimir (2007); Dirks and Ferrin (2002); Gong et al. (2012); Jain et al. (2019); Schaubroeck et al. (2011). Thus, trust in leadership is hypothesised as:
H4: Trust in leadership is positively relates to employee creativity.

\subsection{Defensive silence}

In organizational context defensive silence is referred to a situation wherein an individual suppress facts, views and ideas with a fear of negative consequences such as job termination or denial in promotion" (Chenji \& Sode, 2019). Defensive silence at workplace creates emotional exhaustion, cynicism, increase stress and dissatisfaction (Chenji \& Sode, 2019; Jahanzeb \& Fatima, 2018). Moreover, it is argued that defensive silence occurs when employee want to avoid conflict, maintain harmony and bring self-determination in behaviour (Elizabeth Wolef Morrison \& Milliken, 2000; Shen, Zhang, Yang, \& Liu, 2020). Therefore, literature has showed that defensive silence negatively affects employee motivation, enthusiasm and pro-activeness which in turn decrease employee creativity (Chenji \& Sode, 2019; Jahanzeb \& Fatima, 2018; Elizabeth Wolef Morrison \& Milliken, 2000; Shen et al., 2020).Therefore, the relationship between defensive silence and employee creativity is hypothesised as:

\section{H5: Defensive silence is negatively impact on employee creativity.}

\subsection{Workplace ostracism}

The term ostracism has studied in human resource literature to disclose negative impact of workplace ostracism on employee creativity (Chung, 2018; Ferris, Lian, Brown, \& Morrison, 2015; Zhao, Peng, \& Sheard, 2013). Workplace ostracism is explained as "the degree wherein an employee is excluded to participate in organizational operations and alternatively management engage external individual in company operation" (Ferris et al., 2015; Luu Tuan, 2019). The workplace ostracism is referred to a feeling of an employee that he/she is intentionally excluded in a group and is being ignored. Extending to this employee feels that their existence does not matter for company and they make no difference in organization outcome. Ostracism is also known as social exclusion or social pain that negatively impact on individual attitude and reduce employee productivity. Earlier studies had confirmed negative relationship of workplace ostracism on employee creativity (Chung, 2018; Ferris et al., 2015; Zhao et al., 2013). Thus, workplace ostracism is proposed as:

H6: Workplace ostracism is negatively impact on employee creativity.

\subsection{Employee creativity and perceived organizational performance}

Employee creativity is the extent wherein employee presents innovative, creative, useful and novel ideas for the development of product, process or service (Zhou \& George, 2003). Author like Dewett (2007) asserted that the 
characteristics of novelty and usefulness in ideas are considered the most important determinants of employee creativity. Literature in creativity showed that for creativity ideas should be novel and useful (Tierney et al., 1999; Zhou \& George, 2003). Concerning with perceived organizational performance authors like Wang and Noe (2010) have confirmed that employee creativity brings positive impact in achieving perceived organizational performance. Therefore, and back up by earlier research work conducted by Ha and Lo (2018); Hirst et al. (2009) Wang and Noe (2010) the relationship between employee creativity and organizational performance is proposed as:

H7: Employee creativity has positive influence on perceived organizational performance.

\subsection{Moderating effect of employee proactivity}

Employee proactivity refers to proactive behavior of employee to take charge of current situation, engage and understand that situation in order to provide improved solution at workplace (Elizabeth Wolfe Morrison \& Phelps, 1999). Recent study conducted by Parker et al. (2019) stated that employee proactive work behaviour is a composition of different situation. Precisely, employee proactivity is considered if employee creates improved situation at work place. Next to this Bindl and Parker (2012) stated that employee proactivity reflects to employee goal oriented work behaviour wherein the aim of employee is to bring fastest change in work situation with personal initiative. According to Park et al. (2017) postulated that employee proactivity is a combination of envision, plan, enact and reflect to respond a situation. Previous literature on employee proactivity have emphasized on employee creativity and proactivity (Crant, 2000; Park et al., 2017; Parker et al., 2019). Therefore, this study contributes to body of knowledge by adding moderating role of employee proactivity in predicting the relationship between employee creativity and perceived organizational performance. The moderating role of employee creativity is hypothesized in such a way that it strengthens the relationship between employee creativity and perceived organizational performance (Elizabeth Wolfe Morrison \& Phelps, 1999; Parker et al., 2019). Hence, employee proactivity is hypothesised as:

H8: Employee creativity positively moderates relationship between employee creativity and perceived organizational performance.

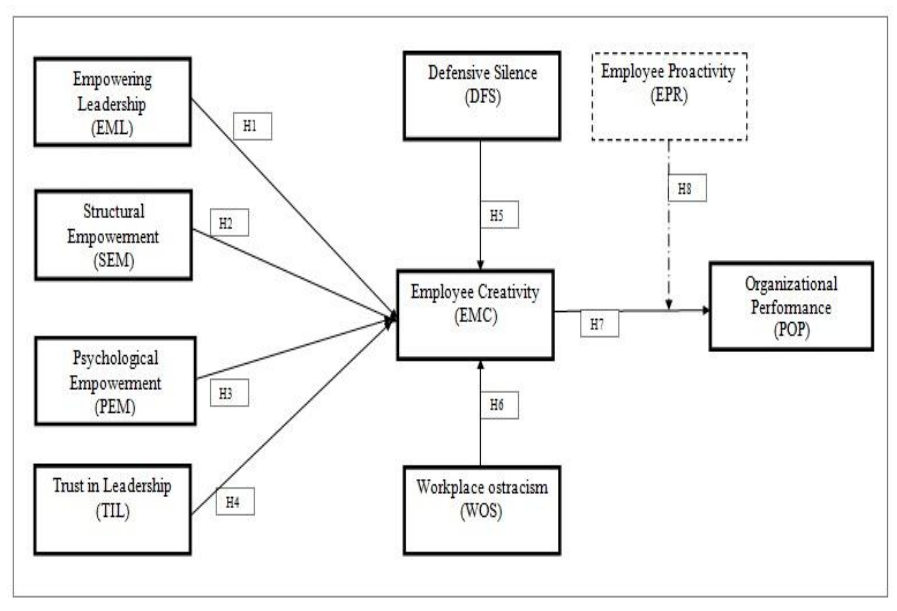

Fig-1: Theoretical framework

\section{Research methodology}

\subsection{Scale development}

The current study develops a research model to investigate employee creativity and organizational performance with positive and negative characteristics of human behavior at workplace. Constructs were measured with scale items adopted from literature that emphasis on employee creativity and organizational performance. Constructs items for empowering leadership were adapted from Zhang and Bartol (2010). Instrument items for structural empowerment are adopted from García-Juan, Escrig-Tena, and Roca-Puig (2019). The third construct relates to empowerment namely psychological empowerment had measured with items scale adopted from Spreitzer (1995) and Taylor (2013). Extending to this the research model has added another leadership construct namely trust in leadership and adapted from Norman, Avolio, and Luthans (2010). Concerning with constructs having negative characteristics such as workplace ostracism and defensive silence were adopted from human resource literature. Workplace ostracism adopted from Ferris, Brown, Berry, and Lian (2008) therefore, scale items for defensive silence adapted from Knoll and Van Dick (2013). Similarly, scale items for employee creativity were adopted from Karwowski, Lebuda, Wisniewska, and Gralewski (2013) and Zhou and George (2001). Scale items for the construct of employee proactivity were adopted from Griffin, Neal, and Parker (2007). All the constructs items were measured with five-point Likert Scale indicating 1 for strongly disagree to 5 for strongly agree in line with Hair, Anderson, Black, and Babin (2016).

\subsection{Sampling and data collection}

The current research model is based in quantitative research approach. A survey questionnaire was developed which included constructs items. Respondents of this study belong to public sector organizations of Saudi Arabia. For sample size help was taken from prior-power analysis using G-power 
Software (Ghani, Rahi, Yasin, \& Alnaser, 2017; S Rahi, 2017). According to Samar Rahi and Abd. Ghani (2019c) prior-power analysis shows accurate size of the sample that is required for inferential analysis. Results of the prior-power analysis indicate the sample size should be larger than 250 . Therefore, earlier studies suggested that larger size of data mitigate sampling error (Samar Rahi, 2019; Samar Rahi \& Abd. Ghani, 2019b). In line with above arguments researcher distributed 650 questionnaires among public sector employees and anticipated to get maximum responses in return. For administrative survey convenience sampling approach was used as recommended by earlier researchers S Rahi (2017); Rowley (2014). Among 650 questionnaires, 413 were returned with a response rate of $63 \%$. These questionnaires were further screened out and 28 were discarded due to inappropriate filling (S Rahi, 2017). Finally, 384 responses were coded and analyzed with structural equation molding (SEM).

\subsection{Common method variance bias (CMV)}

Assessing common method variance bias is essential before computation of structural equation modeling (S. Rahi, 2018). Common method variance bias occurs when study fails to differentiate the difference between constructs (Samar Rahi \& Ishaq, 2020). Therefore, the current study test the common method variance bias with Harman's single factor test following guideline provided by Podsakoff, MacKenzie, Lee, and Podsakoff (2003) and Samar Rahi, Abd.Ghani, and Hafaz Ngah (2019). To test common method variance issue researcher followed the method that suggested the co-variance of first un-rotated factor must be less than $40 \%$. Results of Harman factor analysis showed $23 \%$ of covariance explained by first un-rotated factor which is substantially lower than $40 \%$. These findings confirmed that common method variance is not likely issue in this study.

\section{Data analysis}

For data analysis structural equation modeling was applied using Smart-PLS Software (Ringle, Wende, \& Becker, 2015). Structure equation modeling is the latest statistical approach that estimate causal relations among exogenous and endogenous variables (Hair et al., 2016). Structural equation meddling is assessed with two-stage approach including measurement model and structural model as suggested by Anderson and Gerbing (1988). The detail of both stages is given in the subsequent sections.

\subsection{Assessment of the measurement model}

The measurement model includes estimation of convergent validity and discriminant validity of the constructs. Convergent validity indicates that construct is valid therefore discriminant validity shows how constructs differ with each other. In order to achieve construct reliability researcher followed the values of alpha $(\alpha)$ and composite reliability should be greater than 0.70 . Results indicate that all values of alpha and composite reliability are higher than 0.70 , confirming adequate reliability of the constructs (Rahi Samar \& Abd.Ghani Mazuri, 2019). Next to this, convergent validity is tested with average variance extracted following criterion that the values of AVE should be higher than 0.50 which is in line with S. Rahi (2017). Findings revealed that the AVE values of all constructs are greater than 0.50 and confirmed the convergent validity of the constructs (S. Rahi, 2017). For indicator reliability, the values of loading should be higher than 0.60 as suggested by Hair et al. (2016) and S. Rahi (2017). Results indicate adequate loading hence, confirming reliability of the indicators. Table 1 shows the results of the measurement model including cronbach alpha, average variance extracted and indicator loadings and constructs items.

Table 1. Assessing measurement model

\begin{tabular}{|c|c|c|c|c|}
\hline Scales & Loadings & $(\alpha)$ & $\mathbf{C R}$ & AVE \\
\hline DFS1: Employees remained silent due to the fear of negative consequences. & 0.839 & 0.658 & 0.853 & 0.744 \\
\hline DFS2: Employees remained silent because they fear of disadvantages while speaking. & 0.886 & & & \\
\hline EMC1: Employee creativity introduces practical ideas and improves performance. & 0.844 & 0.876 & 0.915 & 0.729 \\
\hline $\begin{array}{l}\text { EMC2: The use of technology, new techniques and process in business operations are good source of } \\
\text { employee creativity. }\end{array}$ & 0.862 & & & \\
\hline EMC3: Organizing adequate plans to exhibit innovative ideas raise creativity among employees. & 0.867 & & & \\
\hline $\begin{array}{l}\text { EMC4: New ways of doing work and implementing fresh approach to problem introduce creativity } \\
\text { among employees. }\end{array}$ & 0.842 & & & \\
\hline EML1: My supervisor believes in my ability that I will improve my work. & 0.788 & 0.709 & 0.836 & 0.630 \\
\hline $\begin{array}{l}\text { EML2: My supervisor guides me to understand the importance of my work which in turn improves } \\
\text { firm performance. }\end{array}$ & 0.801 & & & \\
\hline $\begin{array}{l}\text { EML3: My supervisor helps me to understand the importance of my job that relates to effectiveness } \\
\text { of the organization. }\end{array}$ & 0.793 & & & \\
\hline EPR1: Employees involve themselves in changes that help organization to perform better. & 0.824 & 0.757 & 0.861 & 0.673 \\
\hline
\end{tabular}




\begin{tabular}{|c|c|c|c|c|c|c|c|c|c|c|}
\hline \multicolumn{5}{|c|}{ EPR2: Employees do work in better ways and made necessary changes proactively to achieve a task. } & \multicolumn{2}{|c|}{0.843} & & & & \\
\hline \multicolumn{5}{|c|}{ EPR3: Improve work with new ideas which in turn boost employee efficiency towards a task. } & \multicolumn{2}{|c|}{0.793} & & & & \\
\hline \multicolumn{5}{|l|}{ PEM1: At workplace I am confident to perform a task skillfully. } & \multicolumn{2}{|c|}{0.827} & 0.861 & \multicolumn{2}{|c|}{0.906} & 0.706 \\
\hline \multicolumn{5}{|l|}{ PEM2: At workplace I am confident that I have necessary skills to do my job. } & \multicolumn{2}{|c|}{0.856} & & & & \\
\hline \multicolumn{5}{|l|}{ PEM3: At workplace I am mastered in my job related task. } & \multicolumn{2}{|c|}{0.833} & & & & \\
\hline \multicolumn{5}{|l|}{ PEM4: My job related tasks are important to me in my organization. } & \multicolumn{2}{|c|}{0.844} & & & & \\
\hline \multicolumn{5}{|l|}{ POP1: Employee creativity enhances the quality of my work. } & \multicolumn{2}{|c|}{0.882} & 0.851 & \multicolumn{2}{|c|}{0.910} & 0.770 \\
\hline \multicolumn{5}{|l|}{ POP2: Efficient outcome of a firm deliver superior organizational performance. } & \multicolumn{2}{|c|}{0.889} & & & & \\
\hline \multicolumn{5}{|c|}{$\begin{array}{l}\text { POP3: New ideas and dynamic capabilities among employees made the venture more sustainable and } \\
\text { improve organizational performance. }\end{array}$} & \multicolumn{2}{|c|}{0.862} & & & & \\
\hline \multicolumn{5}{|l|}{ SEM1: My supervisor share information equally about firm performance. } & \multicolumn{2}{|c|}{0.764} & 0.816 & \multicolumn{2}{|c|}{0.878} & 0.643 \\
\hline \multicolumn{5}{|l|}{ SEM2: My supervisor recommend bonus for achieving firm goals. } & \multicolumn{2}{|c|}{0.821} & & & & \\
\hline \multicolumn{5}{|c|}{$\begin{array}{l}\text { SEM3: In my organization supervisor train subordinates to enhance their leadership and team } \\
\text { building skills. }\end{array}$} & \multicolumn{2}{|c|}{0.795} & & & & \\
\hline \multicolumn{5}{|c|}{ SEM4: My supervisor gives me power to make decision for achieving firm goals. } & \multicolumn{2}{|c|}{0.826} & & & & \\
\hline \multicolumn{5}{|l|}{ TIL1: I trust on my leader that he/she has power to make good decision. } & \multicolumn{2}{|c|}{0.730} & 0.722 & \multicolumn{2}{|c|}{0.844} & 0.645 \\
\hline \multicolumn{5}{|c|}{ TIL2: At work place I can share my feelings, ideas and hopes with manager freely. } & 0.8 & & & & & \\
\hline TIL3: I trust on my leader and never afraid to share my mistakes that I & e at $w$ & place. & & & 0.7 & & & & & \\
\hline WOS1: At workplace my colleagues ignore me and never invite to par & ate in & cussiol & & & 0.8 & & 0.765 & & 865 & 0.681 \\
\hline WOS2: At work place my colleagues avoid to take me out for dinner. & & & & & 0.8 & & & & & \\
\hline WOS3: At work place my colleagues do not talk with me. & & & & & 0.7 & & & & & \\
\hline Convergent validity confirmed the reliability of the construct & SEM & 0.254 & 0.654 & 0.331 & 0.408 & 0.327 & 0.541 & 0.802 & & \\
\hline therefore discriminant validity is yet to be analyzed. The & TIL & 0.353 & 0.398 & 0.393 & 0.465 & 0.246 & 0.343 & 0.399 & 0.803 & \\
\hline approaches namely Fornell and Larcker criteria, Heterotrait- & wos & 0.324 & 0.282 & 0.382 & 0.397 & 0.318 & 0.299 & 0.320 & 0.528 & 0.825 \\
\hline
\end{tabular}

Monotrait Ratio (HTMT) analysis and cross loadings (Fornell \& Larcker, 1981). Fornell \& Larcker criteria projected that square root of AVE must be higher than the corresponding construct correlation indicating that construct is discriminant. Results indicate that the correlation the square root of AVE is greater than corresponding variable correlation. These findings hence confirmed that construct is discriminant and valid for inferential analysis (Fornell \& Larcker, 1981). Results of Fornell \& Larcker analysis are shown in Table 2.

Table 2. Fornell and Larcker's analysis

\begin{tabular}{|l|l|l|l|l|l|l|l|l|l|}
\hline $\begin{array}{l}\text { Construc } \\
\text { ts }\end{array}$ & DFS & EMC & EML & EPR & PEM & POP & SEM & TIL & WOS \\
\hline DFS & $\mathbf{0 . 8 6 3}$ & & & & & & & & \\
\hline EMC & 0.229 & $\mathbf{0 . 8 5 4}$ & & & & & & & \\
\hline EML & 0.550 & 0.334 & $\mathbf{0 . 7 9 4}$ & & & & & & \\
\hline EPR & 0.339 & 0.407 & 0.532 & $\mathbf{0 . 8 2 0}$ & & & & & \\
\hline PEM & 0.309 & 0.472 & 0.267 & 0.305 & $\mathbf{0 . 8 4 0}$ & & & & \\
\hline POP & 0.214 & 0.720 & 0.266 & 0.398 & 0.505 & $\mathbf{0 . 8 7 8}$ & & & \\
\hline
\end{tabular}

Note: Bold and italic values indicate square root of average variance extracted

Discriminant validity is tested with latest approach namely Heterotrait-Monotrait Ratio (HTMT) analysis. The HTMT ratio analysis suggested that the values of HeterotraitMonotrait ratio analysis should be lower than 0.85 or 0.90 indicating discriminant validity of the construct Gold and Arvind Malhotra (2001) and Kline (2011). Results revealed that the values of HTMT are less than 0.85 or 0.90 and confirmed the discriminant validity (Gold \& Arvind Malhotra, 2001; Kline, 2011). The values of Heterotrait-Monotrait ratio analysis can be seen in Table 3 .

Table 3. Heterotrait-Monotrait ratio analysis

\begin{tabular}{|l|l|l|l|l|l|l|l|l|l|}
\hline & DFS & EMC & EML & EPR & PEM & POP & SEM & TIL & WOS \\
\hline DFS & & & & & & & & & \\
\hline EMC & 0.299 & & & & & & & & \\
\hline EML & 0.816 & 0.421 & & & & & & & \\
\hline EPR & 0.479 & 0.496 & 0.717 & & & & & & \\
\hline PEM & 0.409 & 0.537 & 0.339 & 0.379 & & & & & \\
\hline
\end{tabular}




\begin{tabular}{|c|c|c|c|c|c|c|c|c|c|}
\hline POP & 0.285 & 0.821 & 0.334 & 0.494 & 0.589 & & & & \\
\hline SEM & 0.348 & 0.757 & 0.433 & 0.516 & 0.387 & 0.640 & & & \\
\hline TIL & 0.511 & 0.494 & 0.545 & 0.630 & 0.313 & 0.436 & 0.520 & & \\
\hline WOS & 0.460 & 0.340 & 0.514 & 0.518 & 0.396 & 0.367 & 0.401 & 0.728 & \\
\hline
\end{tabular}

The cross loading method was also used to test the discriminant validity of the construct. Thus method suggested that the loading of the construct should be higher when comparing with other constructs loadings (Fornell \& Larcker, 1981; Rahi Samar \& Abd Ghani Mazuri, 2019). Results of the cross loading method showed that the loading of construct is higher with corresponding constructs loading. These findings confirmed the discriminant validity of the construct. The cross loadings of factors are depicted in Table 4.

\section{Table 4: Cross loadings method}

\begin{tabular}{|c|c|c|c|c|c|c|c|c|c|}
\hline & DFS & EMC & EML & EPR & PEM & POP & SEM & TIL & WOS \\
\hline DFS1 & 0.839 & 0.181 & 0.487 & 0.282 & 0.249 & 0.187 & 0.174 & 0.298 & 0.268 \\
\hline DFS2 & 0.886 & 0.213 & 0.465 & 0.302 & 0.282 & 0.184 & 0.258 & 0.310 & 0.290 \\
\hline EMC1 & 0.181 & 0.844 & 0.296 & 0.346 & 0.358 & 0.554 & 0.618 & 0.296 & 0.267 \\
\hline EMC2 & 0.185 & 0.862 & 0.291 & 0.331 & 0.337 & 0.535 & 0.534 & 0.330 & 0.180 \\
\hline EMC3 & 0.213 & 0.867 & 0.292 & 0.355 & 0.435 & 0.616 & 0.493 & 0.316 & 0.242 \\
\hline EMC4 & 0.202 & 0.842 & 0.264 & 0.354 & 0.467 & 0.726 & 0.581 & 0.404 & 0.266 \\
\hline EML1 & 0.339 & 0.296 & 0.788 & 0.533 & 0.239 & 0.244 & 0.265 & 0.370 & 0.349 \\
\hline EML2 & 0.432 & 0.243 & 0.801 & 0.397 & 0.156 & 0.179 & 0.265 & 0.274 & 0.295 \\
\hline EML3 & 0.556 & 0.250 & 0.793 & 0.314 & 0.232 & 0.203 & 0.258 & 0.278 & 0.258 \\
\hline EPR1 & 0.275 & 0.365 & 0.369 & 0.824 & 0.239 & 0.352 & 0.365 & 0.386 & 0.341 \\
\hline EPR2 & 0.233 & 0.306 & 0.420 & 0.843 & 0.276 & 0.311 & 0.302 & 0.335 & 0.317 \\
\hline EPR3 & 0.327 & 0.325 & 0.529 & 0.793 & 0.237 & 0.312 & 0.334 & 0.422 & 0.316 \\
\hline PEM1 & 0.261 & 0.397 & 0.224 & 0.240 & 0.827 & 0.434 & 0.325 & 0.206 & 0.274 \\
\hline PEM2 & 0.250 & 0.422 & 0.184 & 0.243 & 0.856 & 0.431 & 0.278 & 0.198 & 0.236 \\
\hline PEM3 & 0.254 & 0.382 & 0.245 & 0.290 & 0.833 & 0.431 & 0.293 & 0.211 & 0.275 \\
\hline PEM4 & 0.276 & 0.385 & 0.247 & 0.254 & 0.844 & 0.401 & 0.200 & 0.212 & 0.287 \\
\hline POP1 & 0.202 & 0.633 & 0.228 & 0.335 & 0.449 & 0.882 & 0.469 & 0.279 & 0.238 \\
\hline POP2 & 0.196 & 0.677 & 0.289 & 0.362 & 0.456 & 0.889 & 0.525 & 0.379 & 0.298 \\
\hline POP3 & 0.163 & 0.579 & 0.176 & 0.351 & 0.423 & 0.862 & 0.424 & 0.236 & 0.248 \\
\hline SEM1 & 0.265 & 0.443 & 0.275 & 0.313 & 0.262 & 0.390 & 0.764 & 0.310 & 0.220 \\
\hline SEM2 & 0.216 & 0.474 & 0.268 & 0.347 & 0.265 & 0.424 & 0.821 & 0.345 & 0.281 \\
\hline SEM3 & 0.159 & 0.520 & 0.215 & 0.303 & 0.217 & 0.426 & 0.795 & 0.278 & 0.234 \\
\hline SEM4 & 0.191 & 0.626 & 0.301 & 0.346 & 0.299 & 0.481 & 0.826 & 0.346 & 0.285 \\
\hline TIL1 & 0.254 & 0.283 & 0.338 & 0.365 & 0.195 & 0.283 & 0.293 & 0.730 & 0.568 \\
\hline TIL2 & 0.312 & 0.347 & 0.323 & 0.401 & 0.196 & 0.286 & 0.321 & 0.878 & 0.386 \\
\hline TIL3 & 0.280 & 0.325 & 0.290 & 0.355 & 0.203 & 0.262 & 0.348 & 0.795 & 0.345 \\
\hline WOS1 & 0.271 & 0.225 & 0.308 & 0.305 & 0.247 & 0.250 & 0.245 & 0.409 & 0.822 \\
\hline WOS2 & 0.243 & 0.259 & 0.332 & 0.366 & 0.256 & 0.272 & 0.286 & 0.455 & 0.879 \\
\hline WOS3 & 0.296 & 0.211 & 0.307 & 0.307 & 0.290 & 0.214 & 0.261 & 0.446 & 0.772 \\
\hline
\end{tabular}

Note: Indicator loading is showed in bold and italic

\subsection{Structural model evaluation}

Following two-stage approach researcher tests the causal relationship between hypotheses with structural model. Structural model estimates the causal path, multicollinearity, $t$ - statistics and coefficient of determination. Although measurement model has showed adequate vertical collineraity, lateral multicollinearity is yet to be tested. The multicollinearity of the constructs was tested with variance inflation factor (VIF) following criterion that the values of VIF should not be greater than 3.3 when measuring exogenous variable with endogenous variables (Rahi Samar \& Abd.Ghani Mazuri, 2019). The results of the variance inflation factor revealed that all the values of VIF were lower than 3.3 thus, confirming that lateral multicollinearity is not likely issue in this study. The values of the variance inflation factor are depicted in Table 5.

Table 5. The lateral multicollinearity of the constructs

\begin{tabular}{|l|c|c|}
\hline Constructs & $\begin{array}{c}\text { Employee } \\
\text { Creativity }\end{array}$ & $\begin{array}{l}\text { Perceived Organizational } \\
\text { Performance }\end{array}$ \\
\hline Defensive silence & 1.531 & \\
\hline Employee creativity & 1.198 \\
\hline Empowering leadership & 1.611 & \\
\hline Employee proactivity & & \\
\hline Psychological empowerment & 1.236 & \\
\hline Structural empowerment & 1.315 & \\
\hline Trust in leadership & 1.588 & \\
\hline Workplace ostracism & 1.526 & \\
\hline
\end{tabular}

\subsubsection{Hypothesis testing}

Structural model estimates path coefficient $(\beta)$, coefficient of determination $\left(R^{2}\right)$ and t-statistics. For t-statistics bootstrapping procedure was adopted with a re-sample of 3000 as suggested by Samar Rahi and Abd. Ghani (2019a) and Hair Jr, Hult, Ringle, and Sarstedt (2016). Table 6 shows the results of causal relationship between hypotheses.

\section{Table 6. Hypotheses testing}

\begin{tabular}{|l|l|l|l|l|l|}
\hline $\begin{array}{l}\text { Hypothe } \\
\text { sis }\end{array}$ & Relationship & $\begin{array}{c}\text { Direct } \\
\text { effect }( \\
\boldsymbol{\beta})\end{array}$ & SE & $\begin{array}{c}\text { T- } \\
\text { statistics }\end{array}$ & Results \\
\hline H1 & EML -> EMC & 0.095 & 0.016 & $6.033^{* *}$ & Supported \\
\hline H2 & SEM -> EMC & 0.509 & 0.039 & $13.152^{* * *}$ & Supported \\
\hline H3 & PEM -> EMC & 0.287 & 0.031 & $9.358^{* *}$ & Supported \\
\hline H4 & TIL -> EMC & 0.145 & 0.023 & $6.285^{* *}$ & Supported \\
\hline H5 & DFS -> EMC & -0.072 & 0.014 & $5.020^{*}$ & Supported \\
\hline H6 & WOS -> EMC & -0.062 & 0.016 & $3.801 *$ & Supported \\
\hline H7 & EMC -> POP & 0.668 & 0.026 & $25.530^{* *}$ & Supported \\
\hline
\end{tabular}

Note: $*$ indicate level of significance at $* * * p<0.001 ; * * \mathrm{p}<$ $0.01 ; * \mathrm{p}<0.05$; 
Results of the bootstrap revealed that empowering leadership has significant and positive impact on employee creativity and statistically confirmed by H1: $(\beta=0.095$ path coefficient, $\mathrm{t}$ statistics 6.033 , significant at $\mathrm{p}<0.01)$. The second hypothesis is structural empowerment which showed significant and positive impact on employee creativity and established by $\mathrm{H} 2$ : $(\beta=0.509$, t-statistics 13.152, significant at $\mathrm{p}<0.001)$. Similarly, psychological empowerment has indicated significant and positive effect in employee creativity and confirmed by H3: $(\beta=0.287$, t-statistics 9.358 , significant at $\mathrm{p}$ $<0.01)$. Next to this trust in leadership has revealed positive impact in predicating employee creativity and statistically confirmed by H4: $(\beta=0.145$, t-statistics 6.285 , significant at $\mathrm{p}$ $<0.01)$. Concerning with negative constructs including defensive silence and workplace ostracism both have showed significant negative influence on employee creativity and supported by $(\beta=-0.072$, t-statistic 5.020 , significance $\mathrm{p}<$ $0.05 ; \beta=-0.062$, t-statistic 3.801, significant $\mathrm{p}<0.05)$ thus, confirming $\mathrm{H} 5$ and H6. Employee creativity has showed positive and significant influence on perceived organizational performance and supported by $\mathrm{H} 7$ : $(\beta=0.668$, t-value 25.530 , significance $\mathrm{p}<0.01)$. These findings confirmed that underpinning constructs have strong impact in determining employee creativity and perceived organizational performance.

\subsubsection{Coefficient of determination ( ) effect sizes and} predictive relevance

The research model indicates finding in two-folds. First, it investigates employee creativity with empowering leadership, psychological empowerment, structural empowerment, trust in leadership, defensive silence and workplace ostracism and explained $R^{2} 52.4 \%$ variance in employee creativity. Second, the research model is extended with employee creativity and employee proactivity and explained variance $R^{2} 55.1 \%$ in measuring perceived organizational performance. These results indicate substantial power of the research model in determining employee creativity and perceived organizational performance. Moving further, the researcher has examined the actual size of each construct with effect size analysis $\left(f^{2}\right)$. According to Cohen (1988) the significant results confirmed that relationship exist however the actual effect size is determine with effect size analysis. Effect size analysis $\left(f^{2}\right)$ showed that structural empowerment had medium size effect when predicting employee creativity. Therefore, all other construct had showed small effect size. Concerning with perceived organizational performance, results indicate that employee creativity has substantial effect size on organizational performance. Therefore, employee proactivity has showed small effect size. Finally the predictive relevance of the model was checked with blindfolding procedure $Q^{2}$ as suggested by Samar Rahi, Ghani, and Ngah (2020) and Mohammad Ali (2018). In order to confirm that model has adequate predictive power the values of $Q^{2}$ should be higher than "0" (Mohammad Ali Yamin \& Swaiess, 2019). Results indicate that the model has substantial power to predict employee creativity and organizational performance. The values of coefficient of determination, effect size analysis and predictive relevance are shown in following Table 7.

Table 7. Coefficient of determination, predictive relevance and effect size and

\begin{tabular}{|c|c|c|c|c|}
\hline \multicolumn{5}{|c|}{ Employee Creativity (EMC) } \\
\hline Constructs & $R^{2}$ & $Q^{2}$ & $f^{2}$ & Results \\
\hline Employee Creativity (EMC) & 0.524 & 0.364 & & \\
\hline Defensive silence & & & 0.007 & Small \\
\hline Empowering leadership & & & 0.012 & Small \\
\hline Psychological empowerment & & & 0.140 & Small \\
\hline Structural empowerment & & & 0.413 & Medium \\
\hline Trust in leadership & & & 0.028 & Small \\
\hline Workplace ostracism & & & 0.005 & Small \\
\hline \multicolumn{5}{|c|}{ Perceived Organizational Performance (POP) } \\
\hline Constructs & $R^{2}$ & $Q^{2}$ & $f^{2}$ & Result \\
\hline Perceived Organizational Performance (POP) & 0.551 & 0.411 & & \\
\hline Employee creativity & & & 0.830 & Substantial \\
\hline
\end{tabular}




\begin{tabular}{|l|l|l|l|l|}
\hline Employee Proactivity & & & 0.029 & Small \\
\hline
\end{tabular}

Note: Effect size 0.35, Substantial; for Medium; and 0.02 indicates Small

\subsection{Importance and performance analysis}

After confirming hypothesized relationship the research model was further tested with Importance performance matrix analysis. Importance and performance based analysis highlights the importance and performance of the factors by rescaling construct from 0 to 100 (Samar Rahi, 2015; Samar Rahi et al., 2020). For IPMA calculation perceived organizational performance is taken as an outcome variable. Table 8 depicts the results of the importance performance matrix analysis with construct importance and performance.

Table 8. Importance and performance of the constructs (IPMA)

\begin{tabular}{|l|c|c|}
\hline $\begin{array}{l}\text { Underpinned } \\
\text { Variables }\end{array}$ & $\begin{array}{c}\text { Importance of the } \\
\text { constructs/total effect } \\
\text { perceived organizational } \\
\text { performance }\end{array}$ & $\begin{array}{c}\text { Perform } \\
\text { ance } \\
\text { Index }\end{array}$ \\
\hline Defensive silence & -0.054 & 72.307 \\
\hline Employee creativity & 0.691 & 66.900 \\
\hline $\begin{array}{l}\text { Empowering } \\
\text { leadership }\end{array}$ & 0.080 & 72.061 \\
\hline $\begin{array}{l}\text { Employee } \\
\text { proactivity }\end{array}$ & 0.156 & 70.890 \\
\hline $\begin{array}{l}\text { Psychological } \\
\text { empowerment }\end{array}$ & 0.199 & 73.143 \\
\hline $\begin{array}{l}\text { Structural } \\
\text { empowerment }\end{array}$ & 0.392 & 67.951 \\
\hline Trust in leadership & 0.122 & 69.267 \\
\hline Workplace ostracism & -0.049 & 70.186 \\
\hline
\end{tabular}

Results as depicted in Table 8 showed that employee creativity has the highest importance in determining perceived organizational performance. Therefore, structural empowerment has showed second highest importance for perceived organizational performance. Concerning with psychological empowerment, employee proactivity and trust in leadership have showed intermediate level of importance to predict organizational performance. These findings suggested that for managerial implication construct like employee creativity, structural empowerment, psychological empowerment, employee proactivity and trust in leadership are the core construct to enhance organizational performance.
The importance and performance score of the constructs are also shown in IPMA map as exhibited in Fig 2.

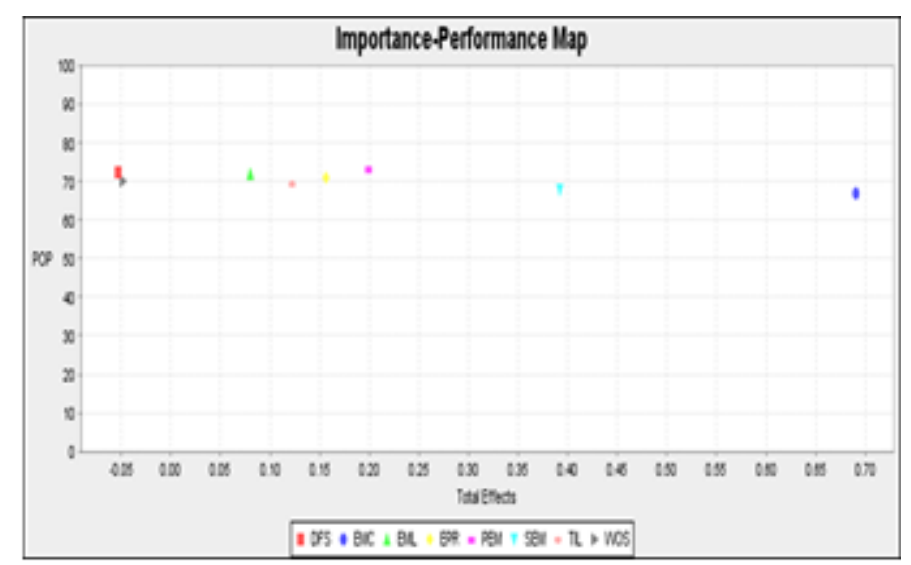

Fig2: IPMA map for construct importance and performance

\subsection{Moderating analysis}

Aside of direct relationship between exogenous and endogenous variable, the current study adds moderating effect of employee proactivity between employee creativity and perceived organizational performance. Therefore, researcher hypothesized that the positive relationship impact on employee creativity and perceived organizational performance in such a way that it strengthens the relationship between perceived organizational performance and employee proactivity. The moderating effect is analyzed with product indictor approach as suggested by S. Rahi (2017). The first step of moderating analysis is to get interaction effect while multiplying employee creativity and employee. Then, the bootstrap procedure was adopted to see the significance level of the path and t-statistics. Findings revealed that employee proactivity significantly moderate the relationship between employee creativity and perceived organizational performance and statistically supported by $\mathrm{H} 8$ ( $\beta=0.138$, t-statistics 3.732 , significant at $\mathrm{p}$ $<0.05)$. Findings of the moderating analysis can be seen in Fig 3. 


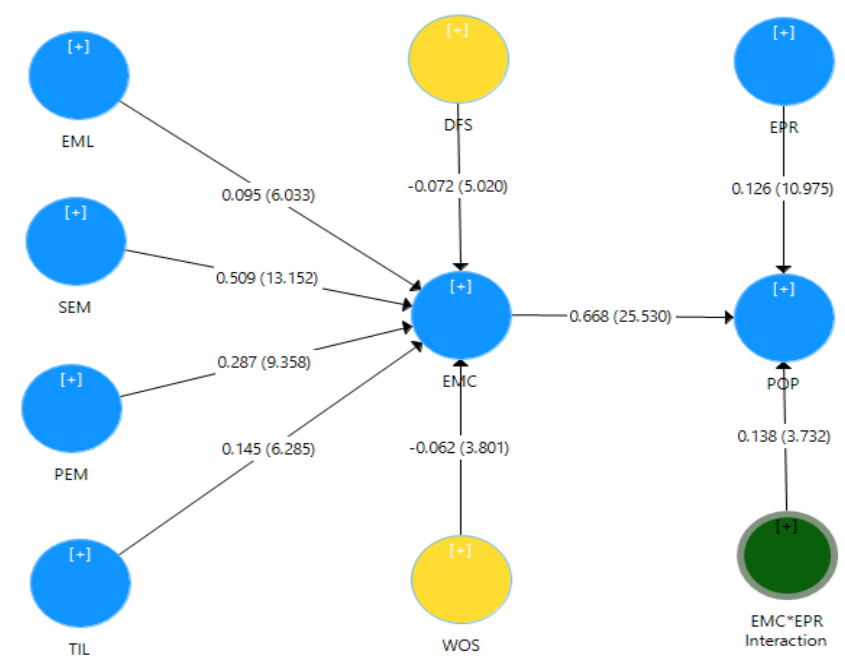

Fig.3 Interaction for moderating effect

Interaction effect confirmed the moderating role between employee creativity and perceived organizational performance. Therefore, the strength of the moderating effect is assessed with simple slope analysis (Rahi Samar \& Abd.Ghani Mazuri, 2019). Simple slope analysis indicates that employee proactivity (EPR) at+1SD shows positive and upward gradient comparing to employee proactivity (EPR) at1SD indicates downward and negative gradient confirming that significant increase is fond between perceived organizational performance and employee creativity with increase in employee proactivity. Simple slope analysis is exhibited in Fig 4 indicate the moderating relationship trend.

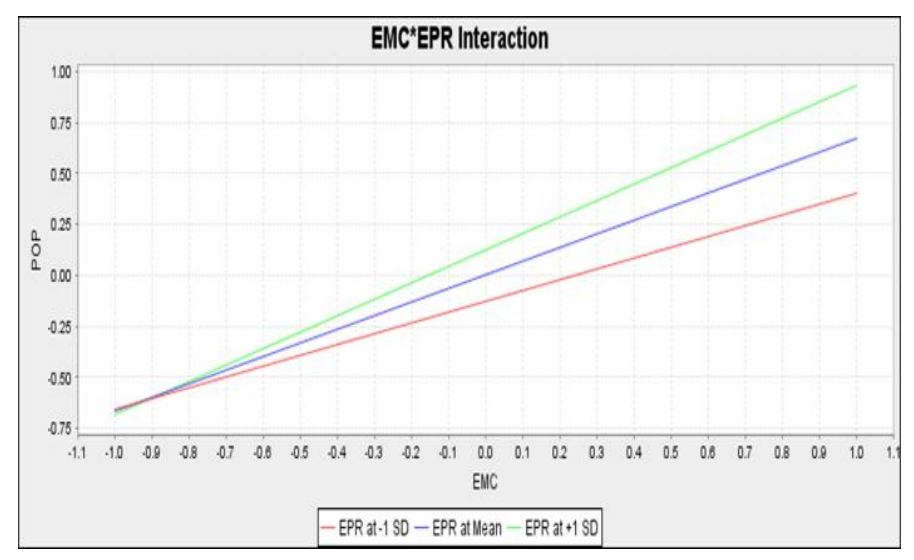

Fig.4 Interaction for moderating effect

\section{Discussion}

The current study aims to investigate employee creativity and perceived organizational performance with empowering leadership, psychological empowerment, structural empowerment, trust in leadership, defensive silence and workplace ostracism. The research model hypothesised positive relationship of empowering leadership, psychological empowerment, structural empowerment and trust in leadership on employee creativity. Therefore, this study includes defensive silence and workplace ostracism into the research model and tested negative impact of these factors on employee creativity. Findings showed that empowering leadership has significant and positive influence on employee creativity and in line with previous studies (Chow, 2018; Wong \& Kuvaas, 2018). The relationship between structural empowerment and employee creativity was found significant and consistent with Fernandez and Moldogaziev (2013). Next to this, researcher has confirmed the relationship between psychological empowerment and employee creativity which is in line with Spreitzer (2008). Similarly, trust in leadership has confirmed positive impact on employee creativity and consistent with previous findings Alkaabi and Wong (2019). Aside of positive relationship, results have confirmed negative impact of defensive silence and workplace ostracism on employee creativity. These findings are consistent with earlier studies Chenji and Sode (2019); Chung (2018); Ferris et al. (2015); Jahanzeb and Fatima (2018); Zhao et al. (2013).

This study contribute to body of knowledge and investigated the moderating role of employee proactivity between employee creativity and perceived organizational performance. The moderating relationship is confirmed in such a way that it strengthens the relationship between employee creativity and perceived organizational performance and confirmed that the relationship between perceived organizational performance and employee creativity will be robust when employee proactivity is higher. Research model has showed substantial variance in employee creativity and perceived organizational performance. Employee creativity was measured with empowering leadership, psychological empowerment, structural empowerment, trust in leadership, defensive silence and workplace ostracism and explained $R^{2}$ $52.4 \%$ variance in measuring employee creativity. Similarly, organizational performance was predicted by employee creativity and employee proactivity and explained $R^{2} 55.1 \%$ variance in predicting perceived organizational performance. The research model had showed substantial variance in employee creativity and perceived organizational performance. Moving further, the predictive relevance of the research model is tested with blindfolding procedure $Q^{2}$ and confirmed that the research model has substantial power to predict employee creativity and organizational performance. Finally, importance performance matrix recommended that managers and policy makers should focus on constructs namely employee creativity, structural empowerment, psychological empowerment, employee proactivity and trust in leadership to boost organizational performance. 


\subsection{Theoretical implications}

Theoretically, this study has several contributions to theory and literature. First, the newly developed research model combines positive (empowering leadership, psychological empowerment, structural empowerment, trust in leadership) and negative factors (defensive silence and workplace ostracism) to determine employee creativity and organizational performance. Therefore, a combination of positive and negative factors enriches the literature in the setting of employee creativity and perceived organizational performance. Second, this study contributes to empowerment theory by adding factors namely trust in leadership, defensive silence and workplace ostracism. The research model is further extended with moderating role of employee proactivity and confirmed the moderating effect of employee proactivity between employee creativity and perceived organizational performance. Thus, integrating employee creativity between empowerment factors, defensive silence, and workplace ostracism provide new insight of relationship which in turn help to enhance employee creativity. Finally, the predictive relevance of the model and variance explained by exogenous factor on endogenous factors had showed substantial impact to predict employee creativity and perceived organizational performance. These findings confirmed the validity of the research model and enrich literature for academic researcher.

\subsection{Practical implications}

Practically, this study can be utilized to understand what factors impact on employee behavior to yield employee creativity and perceived organizational performance. The current proposes a research model that combines positive and negative human resource factors and provides directions to manager for better practices at work place. Human resource managers can boost employee creativity by implementing empowerment strategy which includes empowering leadership, psychological empowerment and structural empowerment. Similarly, workplace ostracism and defensive silence had showed negative impact in predicting employee creativity and perceived organizational performance. These findings may useful for manager to understand how these factors negatively impact on employee creativity and reduce employee creativity. Alternatively, human resource managers can mitigate workplace ostracism and defensive silence from workplace which in turn help them to boost employee creativity and organizational performance. For managerial implication help is taken from importance performance matrix analysis which illustrated that managers should focus on employee creativity, structural empowerment, psychological empowerment, employee proactivity and trust in leadership to boost employee creativity and perceived organizational performance.

\section{Conclusion}

The competitive and rapidly changing business environment requires organizations to be more creative and proactive in their business operations. In this essence the present study has intended to investigate factors that influence on employee creativity and perceived organizational performance. The research model underpinned factors such as empowering leadership, psychological empowerment, structural empowerment and trust in leadership to investigate employee creativity. Finding of the structural equation modelling has revealed significant impact of these factors on employee creativity. In addition to that the effect size analysis showed that structural empowerment has maximum effect size in determining employee creativity. Aside of empowerment a factor, the research model comprises workplace ostracism and defensive silence and confirmed negative impact of these factor on employee creativity. These findings confirmed that employee with defensive silence and work place ostracism characteristics were found less motivated and creative. The research model is further extended with the moderating effect of employee proactivity between employee creativity and perceived organizational performance. Results indicate that employee proactivity moderate and strengthen the relationship between employee creativity and perceived organizational performance. The strength of the model was confirmed as it showed substantial variance $R^{2} 52.4 \%$ in employee creativity and $R^{2} 55.1 \%$ variance in perceived organizational performance. In addition to that the predictive relevance of the research model was tested with blindfolding procedure $Q^{2}$ and confirmed that the research model has substantial power to predict employee creativity and organizational performance. Hence, these findings confirmed the validity of research model in the context of employee creativity and perceived organizational performance. The importance performance matrix suggested that managers and policy makers should focus on constructs namely employee creativity, structural empowerment, psychological empowerment, employee proactivity and trust in leadership in order to enhance the perceived organizational performance.

\subsection{Research limitations and future research directions}

Although the current research contributes to both theory and practice in several ways it has some limitations that is important to acknowledge for further research. First, the current study is cross-section and investigate phenomenon at one point of time. Thus, the longitudinal study could reveal different results. Second, this study is the respondents. Respondents of this study belong to public sector only therefore adding observations from Saudi private sector could reveal interesting findings. Third, the research model does not guarantee to include all variables that impact on employee creativity and perceived organizational performance. 
Therefore, academic research can extend or integrate existing research model with other human resource factors. Finally, the research model is developed and studied in Middle East context. Therefore, replicating this research model in other regions like in South or East Asia could enhance the generalizability of the research model.

\section{References}

[1] Alkaabi, O., \& Wong, C. (2019). Relationships among authentic leadership, manager incivility and trust in the manager. Leadership in Health Services.

[2] Anderson, J. C., \& Gerbing, D. W. (1988). Structural equation modeling in practice: $\mathrm{A}$ review and recommended two-step approach. Psychological bulletin, 103(3), 411.

[3] Auh, S., Menguc, B., \& Jung, Y. S. (2014). Unpacking the relationship between empowering leadership and service-oriented citizenship behaviors: A multilevel approach. Journal of the Academy of Marketing Science, 42(5), 558-579.

[4] Bartram, T., \& Casimir, G. (2007). The relationship between leadership and follower in-role performance and satisfaction with the leader. Leadership \& Organization Development Journal.

[5] Bindl, U. K., \& Parker, S. K. (2012). Chapter 8 affect and employee proactivity: A goal-regulatory perspective. Experiencing and managing emotions in the workplace (Research on Emotion in Organizations), 8, 225-254.

[6] Binyamin, G., \& Brender-Ilan, Y. (2018). Leaders's language and employee proactivity: Enhancing psychological meaningfulness and vitality. European Management Journal, 36(4), 463-473.

[7] Birdi, K., Clegg, C., Patterson, M., Robinson, A., Stride, C. B., Wall, T. D., \& Wood, S. J. (2008). The impact of human resource and operational management practices on company productivity: A longitudinal study. Personnel psychology, 61(3), 467-501.

[8] Biron, M., \& Bamberger, P. (2010). The impact of structural empowerment on individual well-being and performance: Taking agent preferences, self-efficacy and operational constraints into account. Human relations, 63(2), 163-191.

[9] Bowen, D. E., \& Lawler III, E. E. (2006). The empowerment of service workers: What, why, how, and when. Managing innovation and change, 33, 155169.

[10] Chenji, K., \& Sode, R. (2019). Workplace ostracism and employee creativity: role of defensive silence and psychological empowerment. Industrial and Commercial Training.
[11] Chow, I. H. S. (2018). The mechanism underlying the empowering leadership-creativity relationship. Leadership \& Organization Development Journal.

[12] Chung, Y. W. (2018). Workplace ostracism and workplace behaviors: A moderated mediation model of perceived stress and psychological empowerment. Anxiety, Stress, \& Coping, 31(3), 304-317.

[13] Cohen, J. (1988). Statistical power analysis for the behavioural sciences. Hillside. NJ: Lawrence Earlbaum Associates.

[14] Conger, J. A., \& Kanungo, R. N. (1988). The empowerment process: Integrating theory and practice. Academy of management review, 13(3), 471-482.

[15] Crant, J. M. (2000). Proactive behavior in organizations. Journal of management, 26(3), 435-462.

[16] Cuenca Cervera, J. J. (2011). La profesionalización de la dirección de recursos humanos en los Gobiernos locales españoles.

[17] Deci, E. L., \& Ryan, R. M. (2000). The" what" and" why" of goal pursuits: Human needs and the selfdetermination of behavior. Psychological inquiry, 11(4), 227-268.

[18] Dewett, T. (2007). Linking intrinsic motivation, risk taking, and employee creativity in an R\&D environment. R\&D Management, 37(3), 197-208.

[19] Dewettinck, K., \& van Ameijde, M. (2011). Linking leadership empowerment behaviour to employee attitudes and behavioural intentions. Personnel Review.

[20] Dirks, K. T., \& Ferrin, D. L. (2002). Trust in leadership: Meta-analytic findings and implications for research and practice. Journal of applied psychology, 87(4), 611.

[21] Edmondson, A. (1999). Psychological safety and learning behavior in work teams. Administrative science quarterly, 44(2), 350-383.

[22] Farmer, S. M., Van Dyne, L., \& Kamdar, D. (2015). The contextualized self: How team-member exchange leads to coworker identification and helping OCB. Journal of applied psychology, 100(2), 583.

[23] Fernandez, S., \& Moldogaziev, T. (2013). Employee empowerment, employee attitudes, and performance: Testing a causal model. Public Administration Review, 73(3), 490-506.

[24] Ferris, D. L., Brown, D. J., Berry, J. W., \& Lian, H. (2008). The development and validation of the Workplace Ostracism Scale. Journal of applied psychology, 93(6), 1348.

[25] Ferris, D. L., Lian, H., Brown, D. J., \& Morrison, R. (2015). Ostracism, self-esteem, and job performance: When do we self-verify and when do we self-enhance? Academy of management journal, 58(1), 279-297.

[26] Fornell, C., \& Larcker, D. F. (1981). Structural Equation Models With Unobservable Variables and 
Measurement Error: Algebra and Statistics. Journal of marketing Research, 18(3), 382.

[27] Ganster, D. (2008). The effects of empowerment on attitudes and performance: the role of social support and empowerment beliefs. Human Resource Management International Digest.

[28] García-Juan, B., Escrig-Tena, A. B., \& Roca-Puig, V. (2019). The empowerment-organizational performance link in local governments. Personnel Review.

[29] Ghani, M. A., Rahi, S., Yasin, N. M., \& Alnaser, F. M. (2017). Adoption of Internet Banking: Extending the Role of Technology Acceptance Model (TAM) with ECustomer Service and Customer Satisfaction. World Applied Sciences Journal, 35(9), 1918-1929.

[30] Gold, A. H., \& Arvind Malhotra, A. H. S. (2001). Knowledge management: An organizational capabilities perspective. Journal of Management Information Systems, 18(1), 185-214.

[31] Gong, Y., Cheung, S.-Y., Wang, M., \& Huang, J.-C. (2012). Unfolding the proactive process for creativity: Integration of the employee proactivity, information exchange, and psychological safety perspectives. Journal of management, 38(5), 1611-1633.

[32] Griffin, M. A., Neal, A., \& Parker, S. K. (2007). A new model of work role performance: Positive behavior in uncertain and interdependent contexts. Academy of management journal, 50(2), 327-347.

[33] Ha, S. T., \& Lo, M. C. (2018). An empirical examination of knowledge management and organisational performance among Malaysian manufacturing SMEs. International Journal of Business Innovation and Research, 17(1), 23-37.

[34] Hair, J., Anderson, R., Black, B., \& Babin, B. (2016). Multivariate Data Analysis: Pearson Education.

[35] Hair Jr, J. F., Hult, G. T. M., Ringle, C., \& Sarstedt, M. (2016). A primer on partial least squares structural equation modeling (PLS-SEM): Sage Publications.

[36] Harris, T. B., Li, N., Boswell, W. R., Zhang, X. a., \& Xie, Z. (2014). Getting what's new from newcomers: Empowering leadership, creativity, and adjustment in the socialization context. Personnel psychology, 67(3), 567-604.

[37] Hirst, G., Van Dick, R., \& Van Knippenberg, D. (2009). A social identity perspective on leadership and employee creativity. Journal of Organizational Behavior: The International Journal of Industrial, Occupational and Organizational Psychology and Behavior, 30(7), 963-982.

[38] Houston, D. J. (2000). Public-service motivation: A multivariate test. Journal of public administration research and theory, 10(4), 713-728.

[39] Jahanzeb, S., \& Fatima, T. (2018). How workplace ostracism influences interpersonal deviance: The mediating role of defensive silence and emotional exhaustion. Journal of Business and Psychology, 33(6), 779-791.

[40] Jain, P., Duggal, T., \& Ansari, A. H. (2019). Examining the mediating effect of trust and psychological wellbeing on transformational leadership and organizational commitment. Benchmarking: An International Journal.

[41] Jiang, K., Lepak, D. P., Hu, J., \& Baer, J. C. (2012). How does human resource management influence organizational outcomes? A meta-analytic investigation of mediating mechanisms. Academy of management journal, 55(6), 1264-1294.

[42] Karwowski, M., Lebuda, I., Wisniewska, E., \& Gralewski, J. (2013). Big five personality traits as the predictors of creative self-efficacy and creative personal identity: Does gender matter? The Journal of Creative Behavior, 47(3), 215-232.

[43] Kline, R. (2011). Principles and Practice of Structural Equation Modeling, 3rd edn Guilford Press. New York.

[44] Knoll, M., \& Van Dick, R. (2013). Do I hear the whistle...? A first attempt to measure four forms of employee silence and their correlates. Journal of Business Ethics, 113(2), 349-362.

[45] Laschinger, H. K. S., Wong, C. A., \& Grau, A. L. (2012). The influence of authentic leadership on newly graduated nurses' experiences of workplace bullying, burnout and retention outcomes: A cross-sectional study. International journal of nursing studies, 49(10), 1266-1276.

[46] Luu Tuan, T. (2019). Discretionary HR practices and employee well-being: The roles of job crafting and abusive supervision. Personnel Review, 49(1), 43-66. doi: 10.1108/pr-05-2018-0162

[47] Maynard, M. T., Gilson, L. L., \& Mathieu, J. E. (2012). Empowerment - fad or fab? A multilevel review of the past two decades of research. Journal of management, 38(4), 1231-1281.

[48] Maynard, M. T., Luciano, M. M., D'Innocenzo, L., Mathieu, J. E., \& Dean, M. D. (2014). Modeling timelagged reciprocal psychological empowermentperformance relationships. Journal of applied psychology, 99(6), 1244.

[49] Mohammad Ali, Y. (2018). The mediating role of ethical organizational climate between HRM practices and HR outcomes in Public Sector of Saudi Arabia. International Journal of Business Excellence, 0(0). doi: 10.1504/IJBEX.2019.10016985

[50] Mohammad Ali Yamin, \& Swaiess, M. (2019). Investigating Employee creative performance with integration of DeLone and McLean Information system success model and Technology acceptance model: The moderating role of Creative self-efficacy. International 
Journal of Business Excellence, $0(0)$. doi: 10.1504/IJBEX.2019.10024168

[51] Morrison, E. W., \& Milliken, F. J. (2000). Organizational silence: A barrier to change and development in a pluralistic world. Academy of management review, 25(4), 706-725.

[52] Morrison, E. W., \& Phelps, C. C. (1999). Taking charge at work: Extrarole efforts to initiate workplace change. Academy of management journal, 42(4), 403419.

[53] Mostafa, A. M. S., Gould-Williams, J. S., \& Bottomley, P. (2015). High-performance human resource practices and employee outcomes: the mediating role of public service motivation. Public Administration Review, 75(5), 747-757.

[54] Norman, S. M., Avolio, B. J., \& Luthans, F. (2010). The impact of positivity and transparency on trust in leaders and their perceived effectiveness. The leadership quarterly, 21(3), 350-364.

[55] Park, J. G., Kim, J. S., Yoon, S. W., \& Joo, B.-K. (2017). The effects of empowering leadership on psychological well-being and job engagement. Leadership \& Organization Development Journal.

[56] Parker, S. K., Wang, Y., \& Liao, J. (2019). When is proactivity wise? A review of factors that influence the individual outcomes of proactive behavior. Annual Review of Organizational Psychology and Organizational Behavior, 6, 221-248.

[57] Patterson, M. G., West, M. A., \& Wall, T. D. (2004). Integrated manufacturing, empowerment, and company performance. Journal of Organizational Behavior: The International Journal of Industrial, Occupational and Organizational Psychology and Behavior, 25(5), 641665.

[58] Podsakoff, P. M., MacKenzie, S. B., Lee, J.-Y., \& Podsakoff, N. P. (2003). Common method biases in behavioral research: a critical review of the literature and recommended remedies. Journal of applied psychology, 88(5), 879.

[59] Rahi, S. (2015). Moderating role of brand image with relation to internet banking and customer loyalty: a case of branchless banking. The Journal of Internet Banking and Commerce, 20(3).

[60] Rahi, S. (2017). Research design and methods: A systematic review of research paradigms, sampling issues and instruments development. International Journal of Economics \& Management Sciences, 6(2), 1-5.

[61] Rahi, S. (2017). Structural Equation Modeling Using SmartPLS: CreateSpace Independent Publishing Platform.

[62] Rahi, S. (2018). Research Design and Methods: CreateSpace Independent Publishing Platform.
[63] Rahi, S. (2019). Integration of UTAUT model in internet banking adoption context. Journal of Research in Interactive Marketing, 13(3), 411-435. doi: 10.1108/jrim-02-2018-0032

[64] Rahi, S., \& Abd. Ghani, M. (2019a). Does gamified elements influence on user's intention to adopt and intention to recommend internet banking? International Journal of Information and Learning Technology, 36(1), 2-20. doi: doi:10.1108/IJILT-05-2018-0045

[65] Rahi, S., \& Abd. Ghani, M. (2019b). Integration of expectation confirmation theory and self-determination theory in internet banking continuance intention. Journal of Science and Technology Policy Management, 0(0), null. doi: doi:10.1108/JSTPM-062018-0057

[66] Rahi, S., \& Abd. Ghani, M. (2019c). Investigating the role of UTAUT and e-service quality in internet banking adoption setting. The TQM Journal, 31(3), 491-506.

[67] Rahi, S., Abd.Ghani, M., \& Hafaz Ngah, A. (2019). Integration of unified theory of acceptance and use of technology in internet banking adoption setting: Evidence from Pakistan. Technology in Society, 58, 101120.

doi: https://doi.org/10.1016/j.techsoc.2019.03.003

[68] Rahi, S., Ghani, M. A., \& Ngah, A. H. (2020). Factors propelling the adoption of internet banking: the role of e-customer service, website design, brand image and customer satisfaction. International Journal of Business Information Systems, 33(4), 549-569. doi: 10.1504/ijbis.2020.105870

[69] Rahi, S., \& Ishaq, M. (2020). Factors Influencing online Shopping behavior With Mediating Role of Customer Perceived Value. Paper presented at the Economic and Social Development: Book of Proceedings.

[70] Ringle, C. M., Wende, S., \& Becker, J.-M. (2015). SmartPLS 3. Boenningstedt: SmartPLS GmbH.

[71] Rowley, J. (2014). Designing and using research questionnaires. Management Research Review, 37(3), 308-330.

[72] Samar, R., \& Mazuri, A. G. (2019). Does gamified elements influence on user's intention to adopt internet banking with integration of UTAUT and general selfconfidence? International Journal of Business Excellence, 19(3), 394-414.

[73] Samar, R., \& Mazuri, A. G. (2019). Integration of DeLone \& McLean and Self-Determination Theory in internet banking continuance intention context. International Journal of Accounting and Information Management, 27(3).

[74] Schaubroeck, J., Lam, S. S., \& Peng, A. C. (2011). Cognition-based and affect-based trust as mediators of 
leader behavior influences on team performance. Journal of applied psychology, 96(4), 863.

[75] Shapira-Lishchinsky, O., \& Tsemach, S. (2014). Psychological empowerment as a mediator between teachers' perceptions of authentic leadership and their withdrawal and citizenship behaviors. Educational Administration Quarterly, 50(4), 675-712.

[76] Shen, C., Zhang, Y., Yang, J., \& Liu, S. (2020). Abusive supervision and employee creativity: a moderated mediation model. Leadership \& Organization Development Journal, 41(2), 193-207. doi: 10.1108/lodj-03-2019-0146

[77] Singh, A., \& Rangnekar, S. (2020). Empowering leadership in hospital employees. International Journal of Productivity and Performance Management.

[78] Spreitzer, G. M. (1995). Psychological empowerment in the workplace: Dimensions, measurement, and validation. Academy of management journal, 38(5), 1442-1465.

[79] Spreitzer, G. M. (2008). Taking stock: A review of more than twenty years of research on empowerment at work. Handbook of organizational behavior, 1, 54-72.

[80] Spreitzer, G. M., Kizilos, M. A., \& Nason, S. W. (1997). A dimensional analysis of the relationship between psychological empowerment and effectiveness satisfaction, and strain. Journal of management, 23(5), 679-704.

[81] Srivastava, A., Bartol, K. M., \& Locke, E. A. (2006). Empowering leadership in management teams: Effects on knowledge sharing, efficacy, and performance. Academy of management journal, 49(6), 1239-1251.

[82] Taylor, J. (2013). Goal setting in the Australian public service: Effects on psychological empowerment and organizational citizenship behavior. Public Administration Review, 73(3), 453-464.

[83] Tierney, P., Farmer, S. M., \& Graen, G. B. (1999). An examination of leadership and employee creativity: The relevance of traits and relationships. Personnel psychology, 52(3), 591-620.

[84] Wallace, J. C., Johnson, P. D., Mathe, K., \& Paul, J. (2011). Structural and psychological empowerment climates, performance, and the moderating role of shared felt accountability: A managerial perspective. Journal of applied psychology, 96(4), 840.

[85] Wang, S., \& Noe, R. A. (2010). Knowledge sharing: A review and directions for future research. Human resource management review, 20(2), 115-131.

[86] Wong, S. I., \& Kuvaas, B. (2018). The empowerment expectation-perception gap: An examination of three alternative models. Human Resource Management Journal, 28(2), 272-287.

[87] Zhang, X., \& Bartol, K. M. (2010). Linking empowering leadership and employee creativity: The influence of psychological empowerment, intrinsic motivation, and creative process engagement. Academy of management journal, 53(1), 107-128.

[88] Zhao, H., Peng, Z., \& Sheard, G. (2013). Workplace ostracism and hospitality employees' counterproductive work behaviors: The joint moderating effects of proactive personality and political skill. International Journal of Hospitality Management, 33, 219-227.

[89] Zhou, J., \& George, J. M. (2001). When job dissatisfaction leads to creativity: Encouraging the expression of voice. Academy of management journal, 44(4), 682-696.

[90] Zhou, J., \& George, J. M. (2003). Awakening employee creativity: The role of leader emotional intelligence. The leadership quarterly, 14(4-5), 545-568. 